\title{
Chlorella VUlGaris (CHLORELlaCEAE) DOES NOT SECRETE AUTOINHIBITORS AT HIGH CELL DENSITIES ${ }^{1}$
}

\author{
Ramkumar K. Mandalam ${ }^{2}$ and Bernhard O. Palsson ${ }^{3}$ \\ Department of Chemical Engineering, 3074 H.H. Dow Building, University of Michigan, Ann Arbor, Michigan 48109-2136
}

\begin{abstract}
Filtrates (conditioned medium) from high-density Chlorella vulgaris cultures in photobioreactors were obtained and tested for autoinhibitory activity under different conditions. Exponentially growing cells were inoculated at low initial cell concentration $\left(2 \times 10^{5}\right.$ cells $\left./ \mathrm{ml}\right)$ in $90 \%$ conditioned medium $(\mathrm{CM})$ supplemented with $10 \%$ fresh medium (FM) at low (atmospheric) $\mathrm{CO}_{2}$ levels. The time sequence of DNA histograms of cells in CM cultures showed that there is an accumulation of cells with two and four DNA equivalents in the culture over a period of time, signifying a blockage of cells at the division stage of the cell cycle. Examination of the chemical composition of CM showed the presence of high concentrations ( $>10$ $\mathrm{mM}$ ) of bicarbonate. Adding similar bicarbonate concentrations to FM were found to have similar effects as CM cultures, causing blockage of cell division, though the intensity of the blocking effect was lower. The bicarbonate-free $\mathrm{CM}$ did not show any cell cycle modulating or inhibitory activity. The growth of cells cultivated at high $(5 \%) \mathrm{CO}_{2}$ levels in $90 \% \mathrm{CM}$ supplemented with $10 \%$ FM was comparable to $10 \%$ FM cultures, indicating nutrient limitation in $90 \%$ CM culture. When the $90 \% \mathrm{CM}$ culture was supplemented with $100 \%$ nutrients, the growth rate and final cell concentration was similar to $100 \%$ FM culture. Based on these results we conclude that $C$. vulgaris does not secrete any autoinhibitor(s) or cell cycle modulating compound(s) under the conditions from which the CM was obtained.
\end{abstract}

The presence of autoinhibitors in culture filtrates of algae has been reported by several investigators (Pratt and Fong, 1940; Pratt, 1942a; Spoehr et al., 1949). Investigators have also demonstrated that some algae secrete substances that retard or inhibit the growth of other species (Jorgensen, 1956; Harris and Parekh, 1974). Pratt and coworkers were the first to show that Chlorella vulgaris secreted autoinhibitors and reported its properties in a series of papers in the 1940s (Pratt and Fong, 1940; Pratt, 1942a, b, 1944; Pratt, Oneto, and Pratt, 1945). They concluded that the inhibitory compound called "chlorellin" was produced and secreted by $C$. vulgaris cells that retarded its own growth. The amount of this substance produced seemed to be in proportion to the age of the culture (Pratt et al., 1945). The inhibitory compound was found to diffuse through colloidan membranes and its molecules are probably less than $15 \AA \AA$ units in diameter. It was found to be twice as soluble in $95 \%$ ethanol compared to $95 \%$ ether and readily extractable by ether from an alkaline solution (Pratt, 1942a). It was also observed that the inhibitory compounds extracted from old cultures of $C$. vulgaris were found to retard the rate of photosynthesis (Pratt, 1942b). Further investigations on the identity, continued by Spoehr et al., of other species of Chlorella found that the inhibitory compound could be a photooxidation product of unsaturated fatty acids (Spoehr et al., 1949). No definite structure has been established yet for these inhibitors (Glombitza and Koch, 1989).

High-density photoautotrophic C. vulgaris cultures of $3 \%$ fresh weight ( $\mathrm{fw}$ ) have been obtained in specially de-

\footnotetext{
' Manuscript received 17 June 1994; revision accepted 2 February 1995.

The authors thank Mehran Shahabi for his help with the flow cytometric analysis. This project was funded by Grant No. NAGW-2608 from NASA Headquarters.

${ }^{2}$ Current address: Aastrom Biosciences, Inc., P.O. Box 376, Ann Arbor, MI 48106.

${ }^{3}$ Author for correspondence.
}

signed photobioreactors (Javanmardian and Palsson, 1991b). Performance of frequent on-line ultrafiltration (upon reaching a cell concentration of $0.3 \% \mathrm{fw}$ ) was necessary to obtain high cell densities. Population distributions of per cell DNA content before and after ultrafiltration revealed that the cells were blocked at some stage in the cell cycle. This blockage of division led to cessation of growth. Sustained oscillation in cell concentration and average per cell DNA content were observed in continuous cultures of $C$. vulgaris at low dilution rates $(0.1 / \mathrm{d})$ (Javanmardian and Palsson, 1991a). The results suggested that the oscillations are most likely due to the secretion of compounds that alter cell cycle kinetics.

In this study the cell-free filtrates from high-density $C$. vulgaris cultures were analyzed for the presence of any inhibitory/cell cycle modulating compounds and their biological activity. Experiments were conducted at low and high $\mathrm{CO}_{2}$ levels, and with exponentially growing cells.

\section{MATERIALS AND METHODS}

The conditioned medium (CM) was obtained from $C$. vulgaris, UTEX 398 (UTEX Culture Collection of Algae, Austin, Texas) cultures cultivated in N-8 medium (Javanmardian and Palsson, 1991a) in a 3-liter New Brunswick Bioflo II (New Brunswick Scientific, Edison, NJ), with a 2.5-liter working volume. The culture was grown at a constant temperature of $25 \mathrm{C}$ and illuminated by four circular cool white 40-W fluorescent lamps. Air supplemented with $5 \%$ carbon dioxide was sparged through the reactor at a flow rate of $100 \mathrm{ml} / \mathrm{min}$ and the stirrer was set at a speed of $200 \mathrm{rpm}$. The culture was grown to a concentration of $2 \times 10^{8}$ cells $/ \mathrm{ml}$ over a period of $10 \mathrm{~d}$, after which the contents of the bioreactor were drained and centrifuged. The supernatant obtained was then filtered using a $0.22 \mu \mathrm{m}$ filter (Millipore Corporation, Bedford, MA) and used as CM in all experiments. The CM was lyophilized to dry powder in a Lyph-Lock 6-liter 

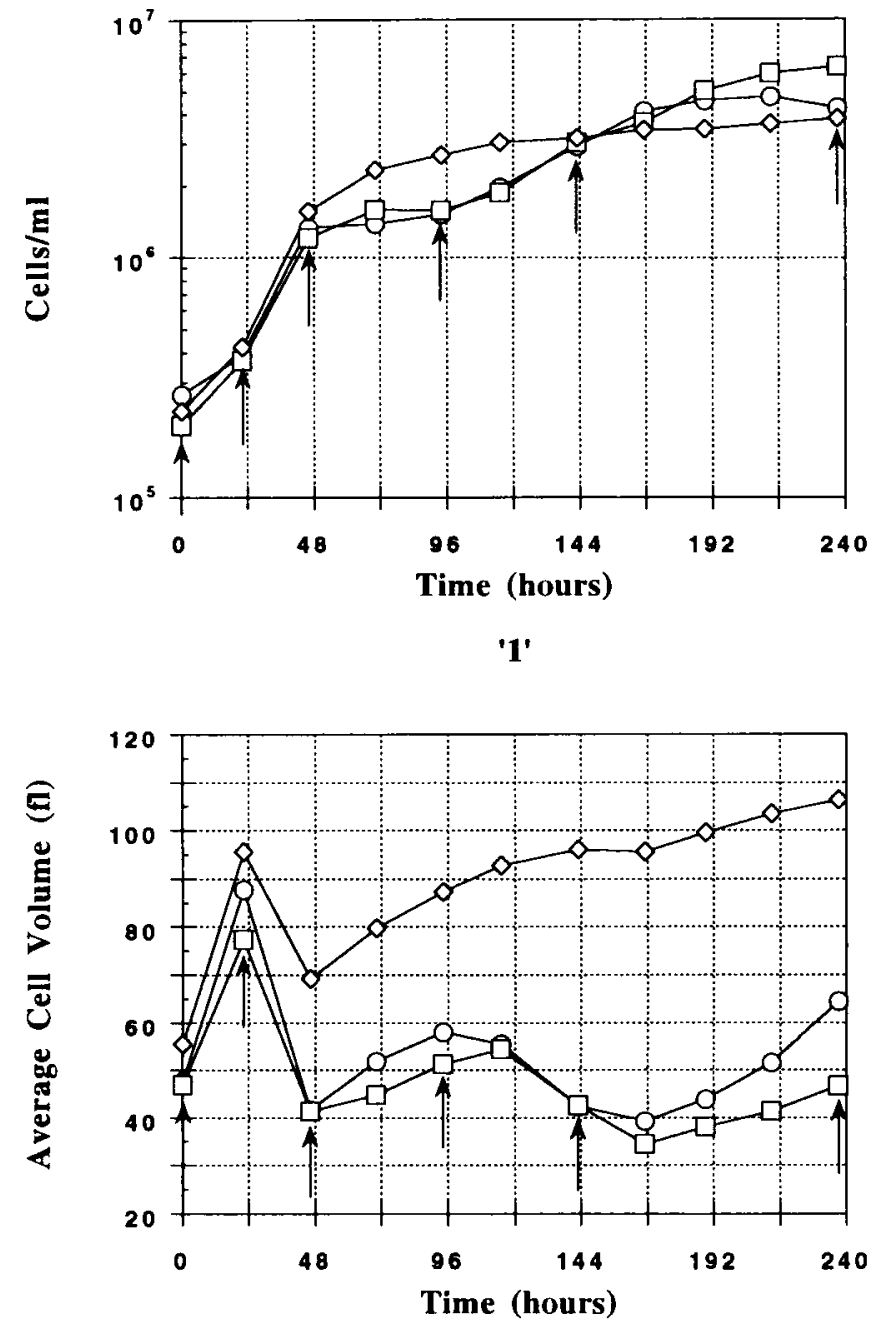

' 2 '

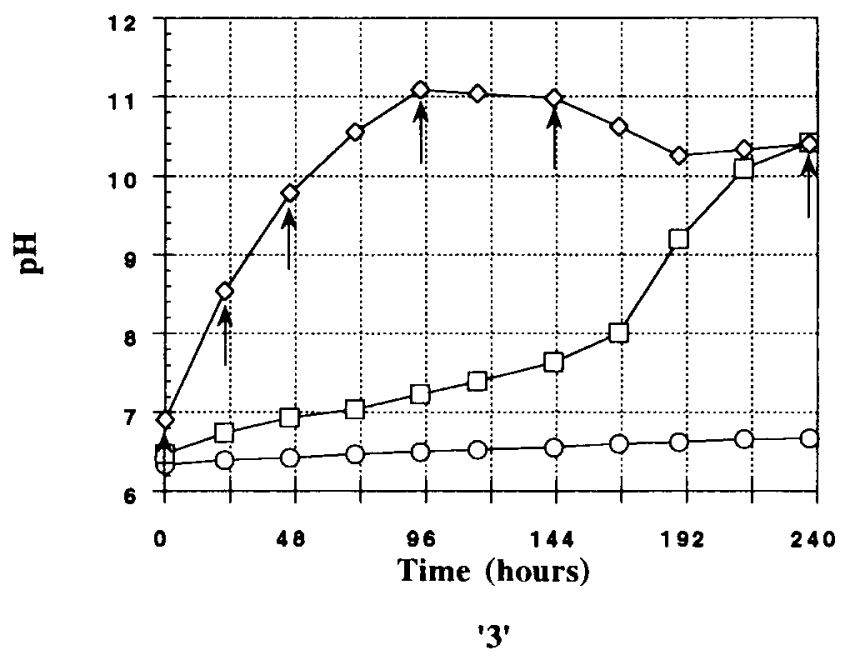

Fig. 1. Growth (1), average cell volume (2), and $\mathrm{pH}$ (3) of C. vulgaris at $0.03 \% \mathrm{CO}_{2}$ in $100 \% \mathrm{FM}$ (circles), $10 \% \mathrm{FM}$ supplemented with $90 \%$ DIW (squares), and 90\% CM supplemented with 10\% FM (diamonds) cultures. The CM was obtained from a culture with $2 \times 10^{8} \mathrm{cells} / \mathrm{ml}$ cell concentration. The arrows indicate the time points at which the DNA histograms are shown in Fig. 2. bench-top freeze-drying system (Model 77520, Labconco Corporation, Kansas City, MO).

The experiments were conducted in 125-ml shaker flasks with $40 \mathrm{ml}$ working volume. C. vulgaris was cultivated at low $\mathrm{CO}_{2}$ levels (air) in N-8 medium (Javanmardian and Palsson, 1991a) at $25 \mathrm{C}$ under a constant light intensity of $300 \mu \mathrm{E} \mathrm{m}^{-2} \mathrm{~s}^{-1}$ in a New Brunswick Scientific G-27 (New Brunswick, Edison, NJ) incubator shaker. Samples were collected every $24 \mathrm{hr}$. High level $\mathrm{CO}_{2}(5 \%$ $\mathrm{CO}_{2}$ and $95 \%$ air) experiments were conducted in spinner flasks illuminated with two circular cool white 22-W fluorescent lamps (General Electric, Inc., Cleveland, OH).

The cell number and average cell volume were measured using Coulter Counter Model ZM (Coulter Electronics, Inc., Hialeah, FL). This unit includes a Coulter Channelyzer C256 (Coulter Electronics, Inc., Hialeah, FL), which can measure particle size distributions. The statistical analysis of size distribution is done via a Coulter AccuComp System for the Channelyzer C256 instrument. The $\mathrm{pH}$ of the cultures was measured using Orion 520A pH meter (Orion Research, Inc., Boston, MA).

The per cell DNA content distribution was obtained using flow cytometry. Samples containing a total of $10^{6}$ cells $/ \mathrm{ml}$ were suspended in $1 \mathrm{ml}$ of ice-cold ethanol. The samples were stored for $48 \mathrm{hr}$ at $4 \mathrm{C}$. Before analyzing the DNA content on the flow cytometer, the samples were centrifuged $(280 \times g, 10 \mathrm{~min})$ and resuspended in methanol for $\mathbf{4 5} \mathrm{min}$ to extract all the remaining chlorophyll. The samples were then centrifuged $(280 \times g, 10 \mathrm{~min})$, washed with phosphate buffer (PBS) solution, then resuspended in $1 \mathrm{mg} / \mathrm{ml}$ of RNase in PBS for $45 \mathrm{~min}$ at 37 $\mathrm{C}$. The DNA was then stained with propidium iodide (PI) in a concentration range of $50 \mu \mathrm{g} / \mathrm{ml}$ for at least $30 \mathrm{~min}$. The samples were then centrifuged and resuspended in $0.3 \mathrm{ml}$ of PBS for flow cytometric analysis.

Stained samples were analyzed on a Coulter EPICS 751 Flow cytometer (Coulter Corporation, Hialeah, FL), equipped with a 5-W argon laser. The laser was tuned to $488 \mathrm{~nm}$, and the power output set to $200 \mathrm{~mW}$. The light energy emitted from the PI-DNA complex was directed to a photomultiplier tube by a $590-\mathrm{nm}$ dichroic beam splitter followed by a $610-\mathrm{nm}$ band-pass filter. The DNA histograms comprising 256 channels on a linear scale were acquired for each sample for a total count of 30,000 . The voltage was adjusted such that all DNA peaks were included in a single linear histogram. The electronic noise and signals generated from cell debris and other noncellular particles were eliminated by gating off two parameter histograms. The region of the noise and noncellular signals was determined by control experiments. Internal standards such as chicken red blood cells could not be used for DNA analysis due to the overlap of the DNA histograms and the samples. The channel number for one DNA equivalent was set by the channel number of the peak of a DNA histogram of a stationary phase control culture.

The bicarbonate concentration was measured in samples, drawn periodically, using the Carbon Dioxide Diagnostics Kit (Procedure No.131-UV) from Sigma Chemical Co., St. Louis, MO. Samples were centrifuged, and the supernatant liquid was used for the assay.

The bicarbonate was removed from the CM using either concentrated phosphoric acid or hydrochloric acid. The $\mathrm{pH}$ was decreased from 7.4 to 6.3 , and the bicarbonate 


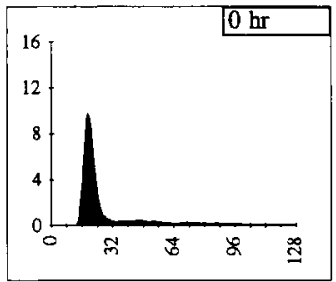

$100 \%$ Fresh Medium, Initial $\mathrm{pH}=6.4$

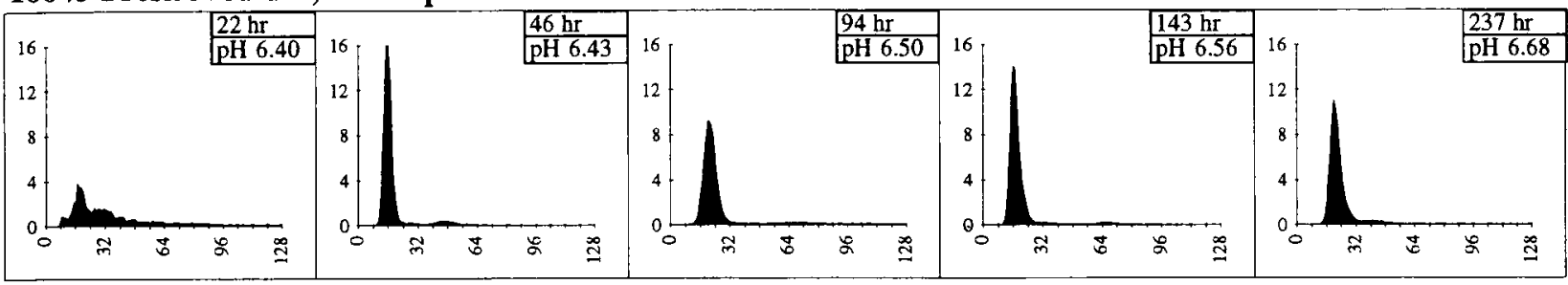

$10 \%$ Fresh Medium, Initial $\mathrm{pH}=6.48$

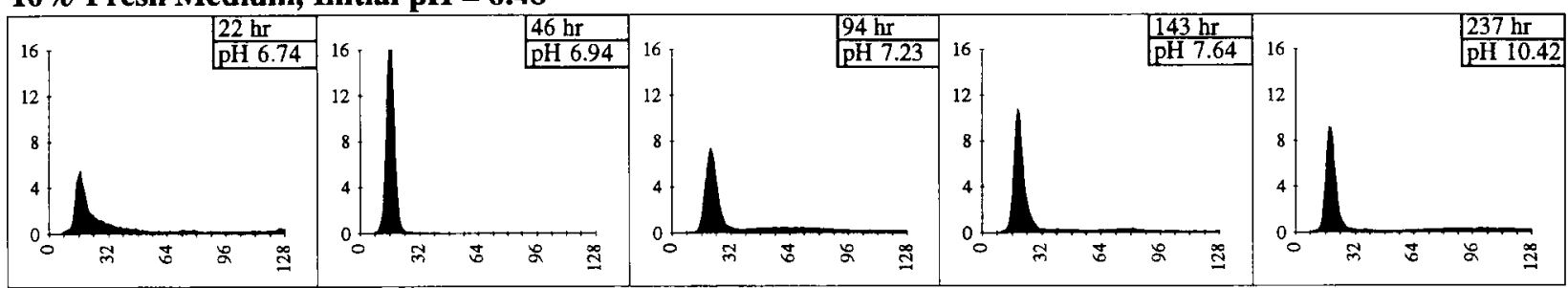

$90 \%$ Conditioned Medium, $10 \%$ Fresh Medium, Initial $\mathrm{pH}=6.91$

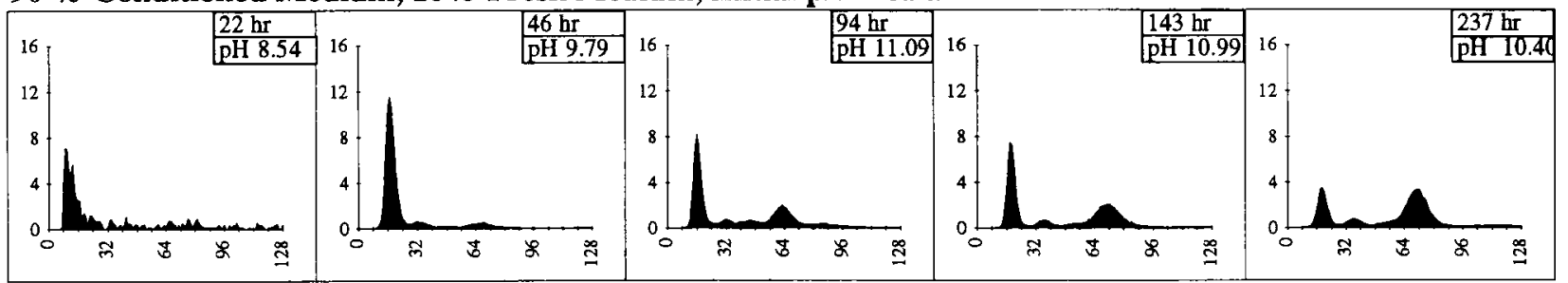

Fig. 2. The time sequence of DNA histograms of $100 \%$ FM, 10\% FM supplemented with $90 \%$ DIW, and $90 \%$ CM supplemented with $10 \%$ FM cultures. All histograms are based on analysis of 30,000 cells except the histograms at time 22 hr for which $1,000-3,000$ cells were analyzed. DNA analysis was carried out at the time points indicated by arrows in Fig. 1.

concentration after the decrease was found to be negligible.

\section{RESULTS}

Effect of CM-Cell growth and cell volume - C. vulgaris cells were grown in 100\% fresh medium (FM), 10\% FM (negative controls), and 90\% CM supplemented with $10 \%$ FM (Fig. 1). The cells reached stationary phase earlier (96 $\mathrm{hr})$ in CM culture than the cells in FM $(200 \mathrm{hr})$. The cells in the FM reached a final cell concentration of $4 \times 10^{6}$ cells $/ \mathrm{ml}$, which is slightly higher than the culture with $\mathrm{CM}$ $\left(3 \times 10^{6}\right.$ cells $\left./ \mathrm{ml}\right)$.

The increase and decrease in the average cell volume (Fig. 1) in the first $48 \mathrm{hr}$ was due to the formation and subsequent release of autospores by mature cells. The average cell volume in CM culture did not decrease as much as control cultures, suggesting that some of the cells had not released their autospores. During the remaining period of cultivation the average cell volume in $\mathrm{CM}$ culture increased, suggesting an increase in population of mature cells with two and four autospores. This volume profile implies that some of the cells committed to DNA replication were blocked irreversibly at the division stage of the cell cycle. This conclusion was further confirmed by the histograms of distribution of DNA content per cell in presence of $\mathrm{CM}$, as described below.

Distribution of DNA content per cell-Chlorella replicates its DNA to produce $2^{n}$ daughter cells per division burst. The mature cells divide to produce two, four, or eight daughter cells depending on the culture conditions (Morimura, 1959; Tamiya et al., 1961; Tamiya, 1964; Donnan, Carvill, and John, 1985). Cells were collected at regular intervals from the FM and CM cultures and analyzed for the distribution of the DNA content per cell using the flow cytometer. At the start of the experiment the distribution is the same in all the cultures as indicated 


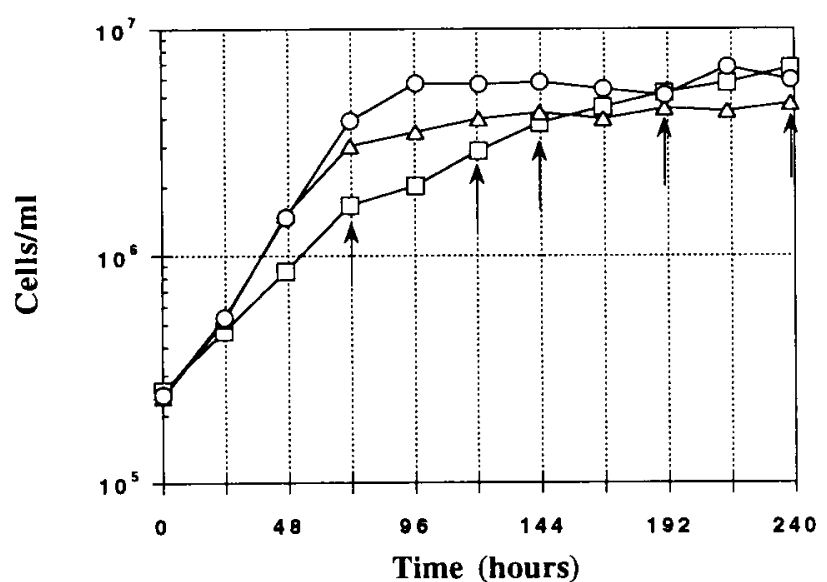

'1'

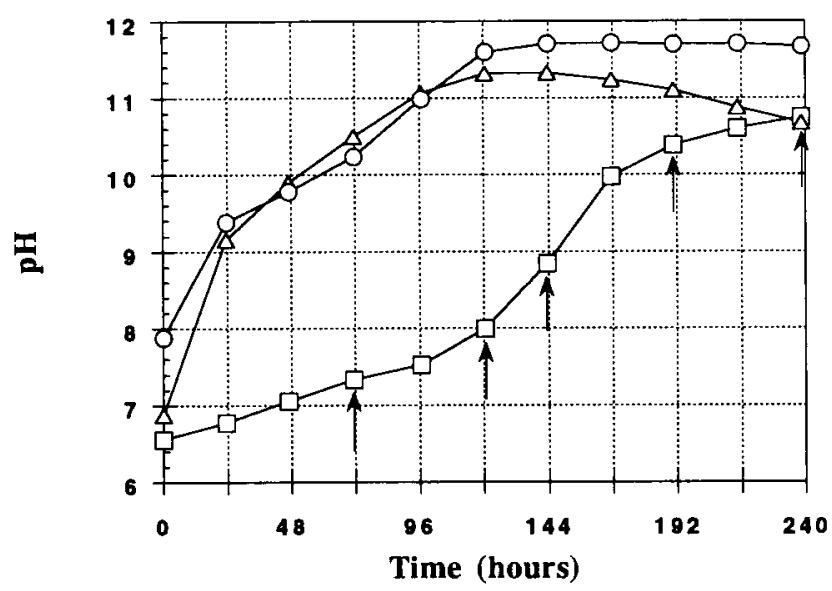

'3'

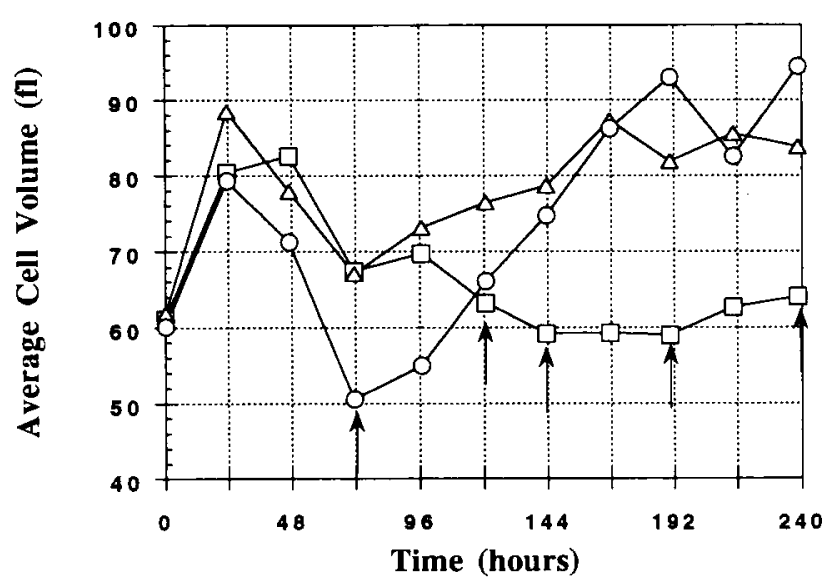

'2'

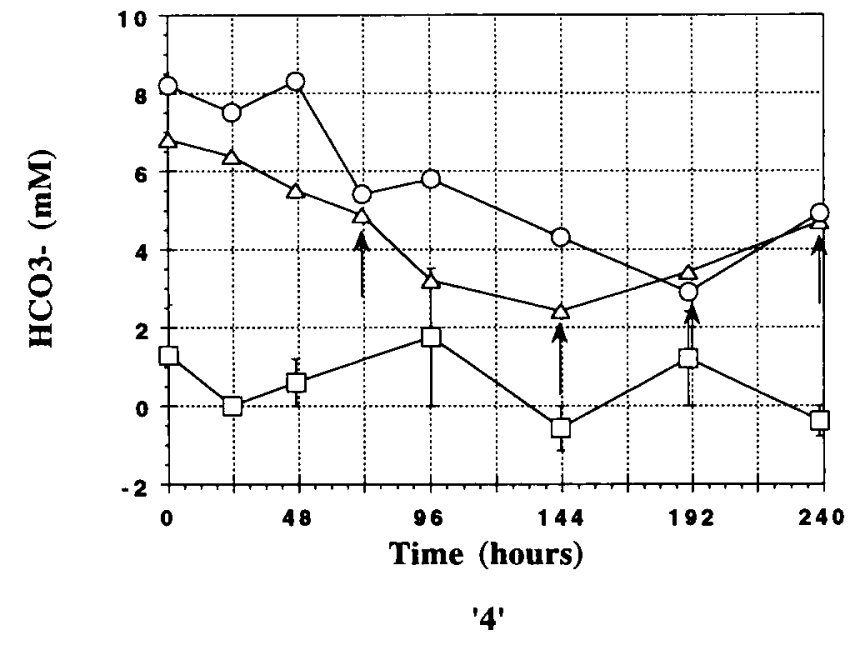

Fig. 3. Growth (1), average cell volume (2), $\mathrm{pH}(3)$, and $\mathrm{HCO}_{3}$ concentration (mM) (4) of $C$. vulgaris at $0.03 \% \mathrm{CO}_{2}$ in $10 \% \mathrm{FM}$ (squares), $90 \%$ $\mathrm{CM}$ and $10 \% \mathrm{FM}$ (triangles), and $90 \% 10 \mathrm{mM} \mathrm{HCO}_{3}$ and $10 \% \mathrm{FM}$ cultures (circles). The arrows indicate the time points at which the DNA histograms are shown in Fig. 5.

in the histogram at $0 \mathrm{hr}$ (Fig. 2). The cultures containing $100 \%$ and $10 \%$ FM showed a unimodal distribution of DNA content per cell throughout the period of cultivation (Fig. 2). The peak of the distribution fluctuates around the region of one DNA equivalent (amount of total DNA present in a single diploid cell), which corresponds to a channel \#16-20. In the presence of CM, the distribution of DNA content per cell resolves into at least three peaks at one, two, and four DNA equivalents (Fig. 2). The population of cells at four DNA equivalents and the ratio of the cells with four DNA equivalents (Channel \#72) to one DNA equivalent (Channel \#18) increases with time. These data indicate that the single cells go through DNA replication, but do not divide. There is also a small but distinct population at two equivalents of DNA (Channel \#36). After $237 \mathrm{hr}$ there are no changes in the population of the cells with one, two, and four DNA equivalents. The change in DNA distribution pattern suggests that the factors present in the CM directly or indirectly inhibit cell division.
pH of the culture-The $\mathrm{pH}$ of the culture was monitored simultaneously with the cell count and DNA content per cell distribution. The $\mathrm{pH}$ of the culture with $100 \%$ FM does not increase significantly (6.4 to 6.8) over the entire period of cultivation (Fig. 1). The culture containing $10 \%$ FM increases gradually from 6.5 to 8.0 in $167 \mathrm{hr}$ and then rises sharply to 10.42 in another $70 \mathrm{hr}$. The sharp increase can be attributed to the reduced buffering capacity of the $10 \% \mathrm{FM}$. The initial $\mathrm{pH}$ of the culture in the presence of CM was 6.9 compared to 6.4 or 6.5 in the control cultures. The $\mathrm{pH}$ increases sharply from 6.9 to 11.0 in $94 \mathrm{hr}$ and then levels off for $\approx 50 \mathrm{hr}$ before decreasing to 10.3 . The $\mathrm{pH}$ of the $90 \% \mathrm{CM}$, in the absence of cells when exposed to similar environmental conditions (room temperature, gas exchange, and illumination) of the culture, increased by only 1.0 unit in $10 \mathrm{hr}$ and stayed at that $\mathrm{pH}$.

Characterization of factors responsible for cell cycle modulation - The CM was lyophilized to dryness, redissolved in deionized water, and checked for activity (ac- 
$10 \%$ Fresh Medium, Initial pH $=6.55$

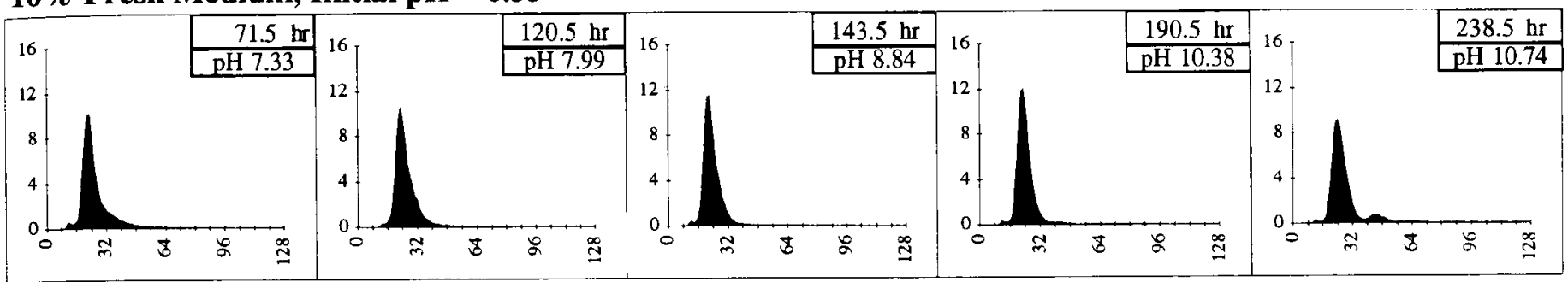

90\% Conditioned Medium, 10\% Fresh Medium; Initial pH $=6.87$

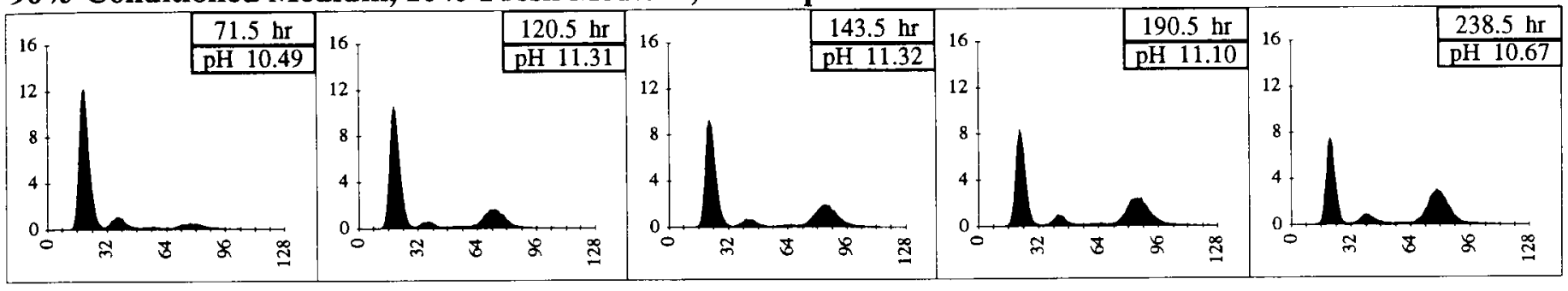

\section{$90 \% 10 \mathrm{mM}$ Bicarbonate, $10 \%$ Fresh Medium, Initial $\mathrm{pH}=7.88$}

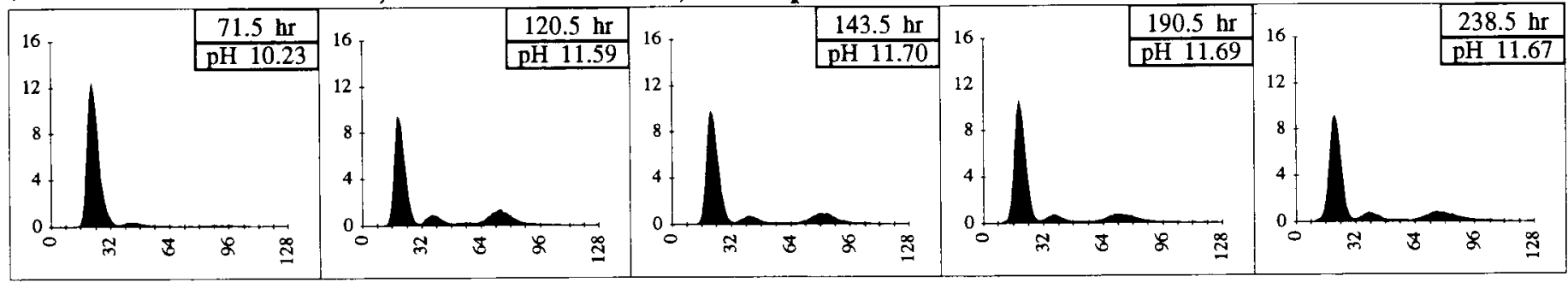

Fig. 4. The time sequence of DNA histograms of $C$. vulgaris in $10 \% \mathrm{FM}, 90 \% \mathrm{CM}$ and $10 \% \mathrm{FM}$, and $90 \% 10 \mathrm{mM} \mathrm{HCO}_{3}$ and $10 \% \mathrm{FM}$ cultures. All histograms are based on analysis of 30,000 cells. DNA analysis was carried out at the time points indicated by arrows in Fig. 4.

cumulation of cells at higher DNA equivalents). The cell cycle regulating activity (accumulation of cells with two and four DNA equivalents) was retained confirming that the factor(s) responsible for the activity were nonvolatile. Attempts were made to identify major functional groups present in the concentrated CM. The IR spectra displayed bands at 704,832,1008, 1407 and $1634 \mathrm{~cm}^{-1}$, which are typical of bicarbonate molecules. Thus, the possibility of presence of dissolved inorganic carbon (DIC) in the form of $\mathrm{CO}_{2}$ and $\mathrm{HCO}_{3-}$ in the $\mathrm{CM}$ was investigated.

The concentration of DIC in the CM was assayed and was found to be $11.8 \mathrm{mM}$. The reaction in this assay occurs at $\mathrm{pH} 8.0$ and measures $\mathrm{HCO}_{3}$ - ion concentration. Experiments were designed to study the effect of such high $(10 \mathrm{mM}) \mathrm{HCO}_{3}$ concentration in the medium.

Effect of bicarbonate concentration-A medium of $90 \%$ $10 \mathrm{mM}$ sodium bicarbonate solution supplemented with $10 \%$ regular $\mathrm{N}-8$ medium was made to simulate the $\mathrm{HCO}_{3}$ conditions in the CM. Negative controls $(100 \% \mathrm{~N}-8 \mathrm{me}-$ dium and $10 \% \mathrm{~N}-8$ medium), positive control (90\% CM, $10 \% \mathrm{~N}-8$ medium), and the medium supplemented with bicarbonate (henceforth referred to as bicarbonate culture) were inoculated with $C$. vulgaris to study the relative effects of $\mathrm{CM}$ and $\mathrm{HCO}_{3}$ solution. The results of only $10 \% \mathrm{FM}, 90 \% \mathrm{CM}$, and the bicarbonate-supplemented culture has been shown to avoid crowding of the plots.
Cell growth and cell volume-The bicarbonate culture had a higher final cell concentration than the CM cultures even though the growth rate during the exponential phase of growth was the same (Fig. 3). The average cell volume in all three cultures increased in the first $24-48 \mathrm{hr}$, indicating the formation of mature cells with developed autospores (Fig. 3). Within the next $24 \mathrm{hr}$ cell division occurred and the average cell volume dropped to $50 \mathrm{fem}$ toliters (fl: $10^{-15} \mathrm{l}$ ) in the case of bicarbonate culture and to $70 \mathrm{fl}$ in $\mathrm{CM}$ culture. The average cell volume in the $90 \% \mathrm{CM}$ culture increased again due to the formation of autospores inside the mature cell and prevention of their release. A similar but delayed buildup of autospores within the mother cell was observed in the bicarbonate culture with average cell volume increasing from $50 \mathrm{fl}$ to $90 \mathrm{fl}$.

Distribution of DNA content per cell-The distribution of DNA content per cell of the bicarbonate culture is compared to the CM and 10\% FM cultures (Fig. 4), with each row showing the time sequence of histograms under a particular condition. The 10\% FM culture showed unimodal distribution for most of the period of cultivation. The cultures in CM and bicarbonate culture showed increasing accumulation of cells with two and four DNA equivalents. The accumulation of multiple-nuclei cells is higher in the CM culture compared to the bicarbonate culture. For instance, at $71.5 \mathrm{hr}$ the histogram of the 


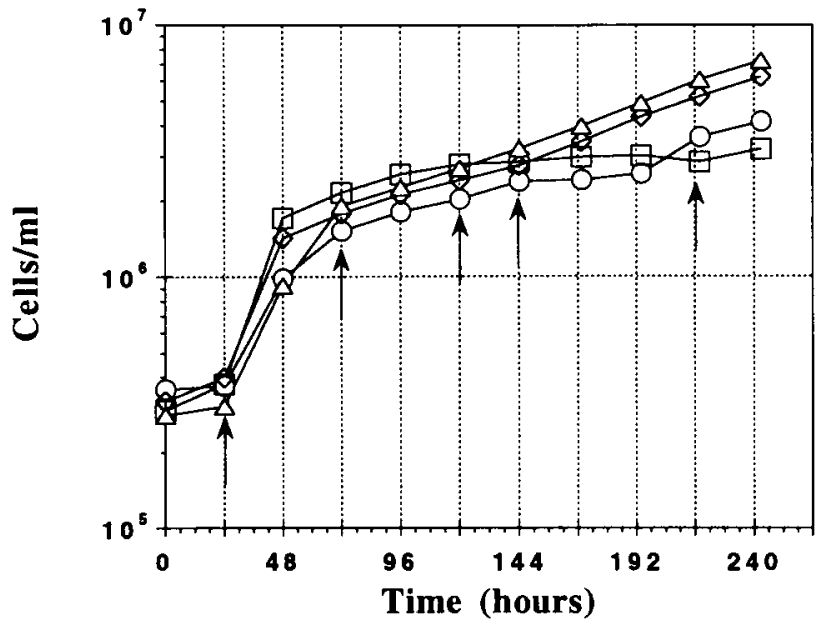

'1'

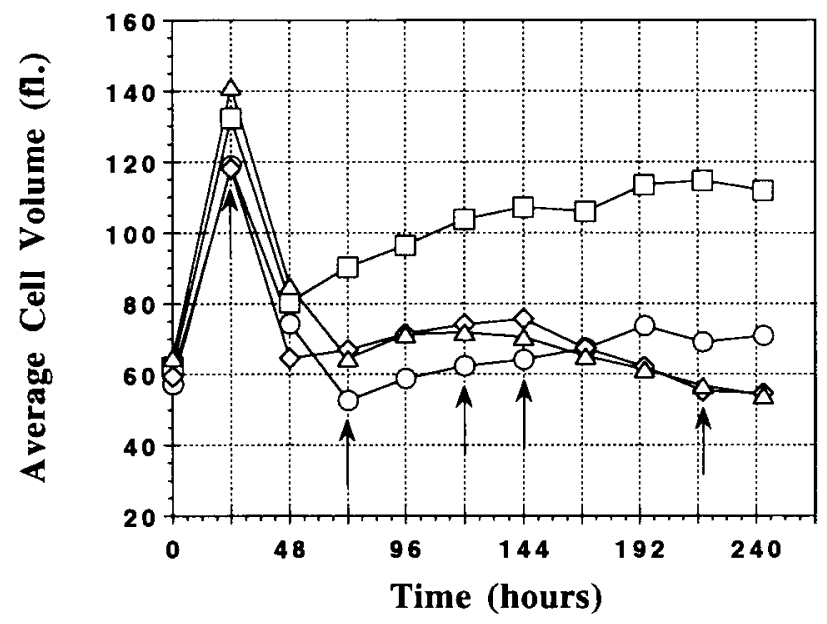

121

Fig. 5. Growth (1) and average cell volume (2) of C. vulgaris at $0.03 \% \mathrm{CO}_{2}$ in $10 \% \mathrm{FM}$ (circles), $90 \% \mathrm{CM}$ and $10 \% \mathrm{FM}$ (squares), $90 \% \mathrm{HCO}{ }_{3-}$ free $\mathrm{CM}$ (using phosphoric acid) and 10\% FM (diamonds), and $90 \% \mathrm{HCO}_{3}$-free $\mathrm{CM}$ (using hydrochloric acid) and $10 \%$ FM cultures (triangles). The arrows indicate the time points at which the DNA histograms are shown in Fig. 7.

bicarbonate culture showed a relatively smaller population at two and four DNA equivalents of DNA compared to CM culture, implying that the blockage of cell division is more pronounced and faster in the CM culture than in the bicarbonate culture. This enhanced activity is observed more clearly in the later period of cultivation. The population of cells at two and four DNA equivalents in the bicarbonate culture did not change significantly compared to the CM culture in which the ratio of cells with four DNA equivalents to cells with one DNA equivalent increased with time. Thus, the accumulation of cells with multiple DNA equivalents in the CM cultures is probably due to the bicarbonate effect, but the enhanced activity could be due to additional factors in the CM.

$\mathrm{pH}$ and $\mathrm{HCO}_{3-}$ concentration of the culture-The $\mathrm{pH}$ profiles of the $\mathrm{CM}$ and bicarbonate culture are very similar up to $168 \mathrm{hr}$ (Fig. 3) even though the initial $\mathrm{pH}$ of the bicarbonate culture was 7.9 compared to 6.9 of the $\mathrm{CM}$ culture. This suggests that the difference in the average cell volume and DNA distribution between 72 and 144 $\mathrm{hr}$ is not a $\mathrm{pH}$ effect. The cells consume $\mathrm{HCO}_{3-}$ in the form of $\mathrm{CO}_{2}$ and release the hydroxyl ion to the extra cellular medium. Thus, increase in $\mathrm{pH}$ will be accompanied by a decrease in $\mathrm{HCO}_{3}$ - concentration as is observed in Fig. 3. The decrease in bicarbonate concentration is almost the same (around $4 \mathrm{mM}$ ) in both the CM and bicarbonate cultures. The $\mathrm{HCO}_{3}$ concentration observed in the 10\% FM culture was negligible (Fig. 3).

Effect of bicarbonate-free $\boldsymbol{C M}$-Bicarbonate was removed from the CM by decreasing the $\mathrm{pH}$ as described earlier. The results of four conditions reported here are $10 \%$ FM culture (negative control); $90 \% \mathrm{CM}$ and $10 \%$ FM culture (positive control); $90 \% \mathrm{HCO}_{3}$ - free $\mathrm{CM}\left(\mathrm{HCO}_{3}\right.$ removed using phosphoric acid) and 10\% FM culture; and $90 \% \mathrm{HCO}_{3-}$ free $\mathrm{CM}\left(\mathrm{HCO}_{3-}\right.$ removed using hydrochloric acid) and 10\% FM culture.
Cell growth and cell volume-The final cell concentrations of the $\mathrm{HCO}_{3-}$-free $\mathrm{CM}$ cultures were higher than the other two cultures (Fig. 5). The average cell volume profile (Fig. 5) of the $\mathrm{HCO}_{3}$-free $\mathrm{CM}$ cultures did not show any significant increase compared to the $90 \% \mathrm{CM}$ culture and was comparable to the $10 \%$ FM culture.

Distribution of DNA content per cell and pH of the culture-The distribution of DNA content per cell of the $\mathrm{HCO}_{3-}$-free $\mathrm{CM}$ cultures exhibits unimodal distribution throughout the period of cultivation (Fig. 6) without any emergence of multiple peaks. The $\mathrm{pH}$ of the two $\mathrm{HCO}_{3-}-$ free CM cultures did not increase significantly. The final $\mathrm{pH}$ of the $\mathrm{HCO}_{3}$-free $\mathrm{CM}$ culture with phosphoric acid was lower (6.72) compared to the $\mathrm{HCO}_{3}$-free $\mathrm{CM}$ culture with hydrochloric acid and this was probably due to the buffering capacity of the phosphate culture.

Effect of CM cultures at high $\mathrm{CO}_{2}$ levels - The presence of any bioactive basic compound in the $\mathrm{CM}$ would be neutralized and rendered inactive by the addition of acids. To investigate if such basic compounds had been neutralized, an alternate method of maintaining the $\mathrm{pH}$ was implemented. To avoid such reactions the $\mathrm{pH}$ was kept from increasing by bubbling $5 \% \mathrm{CO}_{2}$ in the medium; $100 \%$ FM, $10 \% \mathrm{FM}, 90 \% \mathrm{CM}$ with $10 \% \mathrm{FM}$, and $90 \% \mathrm{HCO}_{3--}$ free CM with $10 \%$ FM cultures bubbled with $5 \% \mathrm{CO}_{2}$ were monitored. Also, 100\% FM culture was compared to $90 \% \mathrm{CM}$ in $100 \% \mathrm{FM}$ culture.

Cell growth and cell volume-The growth rates, the final cell concentrations $\left(4 \times 10^{7}\right.$ cells $\left./ \mathrm{ml}\right)$ (Fig. 7$)$, and the volume profile (Fig. 7) of the three 10\% FM with or without CM were very similar. The $100 \% \mathrm{FM}$ culture reached a much higher final cell concentration $\left(3 \times 10^{8}\right.$ cells $\left./ \mathrm{ml}\right)$ than the other three cultures, indicating that the $10 \%$ FM cultures are nutrient limited when cultivated at $5 \% \mathrm{CO}_{2}$. This was very evident when the growth of cells in the $90 \%$ 
90\% Conditioned Medium (CM), 10\% Fresh Medium; Initial pH $=7.67$

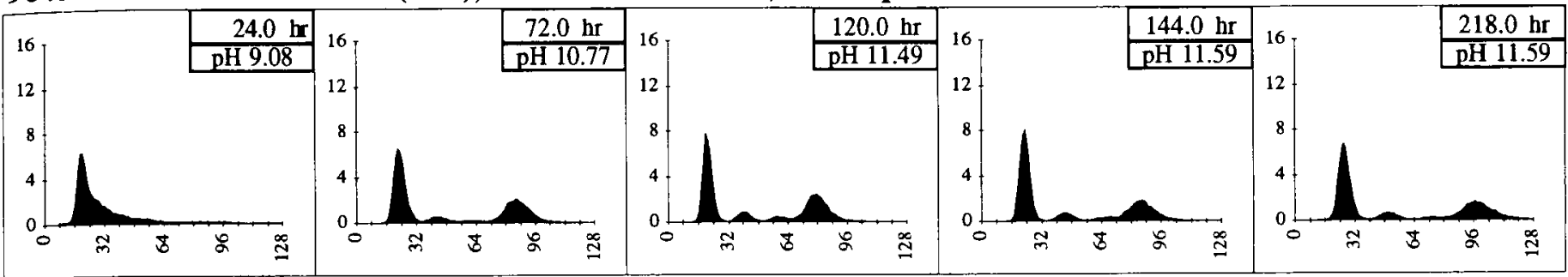

90\% Bicarbonate-free CM (H3PO4), 10\% FM; Initial pH = 6.36

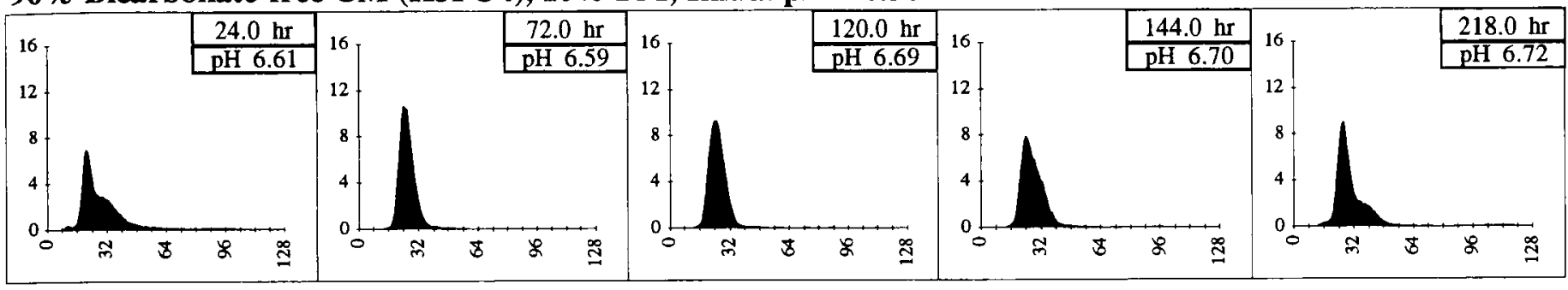

$90 \%$ Bicarbonate-free $\mathrm{CM}(\mathrm{HCl}), 10 \%$ FM, Initial pH $=7.08$

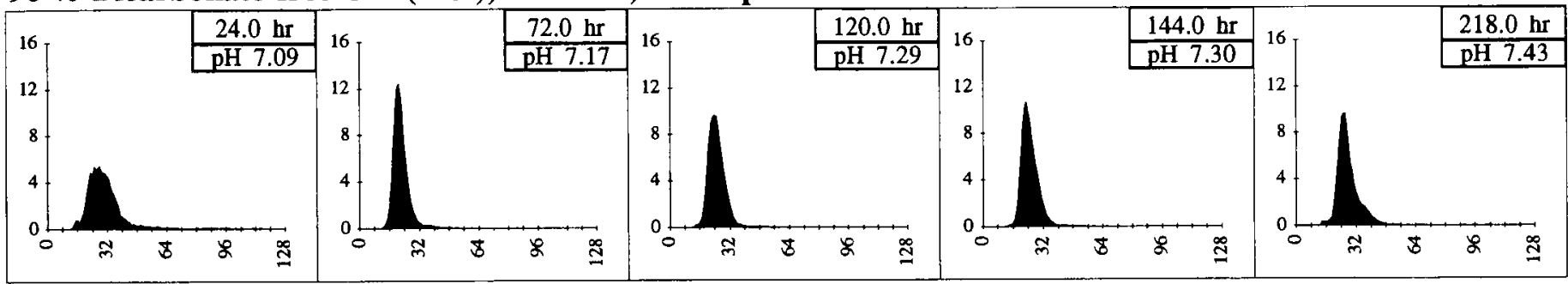

Fig. 6. The time sequence of DNA histograms of $C$. vulgaris in 10\% FM, 90\% CM and 10\% FM, 90\% HCO - -free CM (using phosphoric acid)

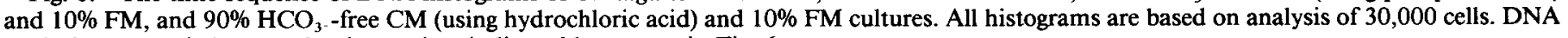
analysis was carried out at the time points indicated by arrows in Fig. 6.

CM culture containing 100\% FM components was compared to the growth in $100 \%$ FM (Fig. 8). No differences in the growth rates (Fig. 8) and average cell volume (Fig. 8) were observed. Thus, there is no evidence of inhibition of growth or cell division in the presence of $\mathrm{CM}$ when cultivated at $5 \% \mathrm{CO}_{2}$.

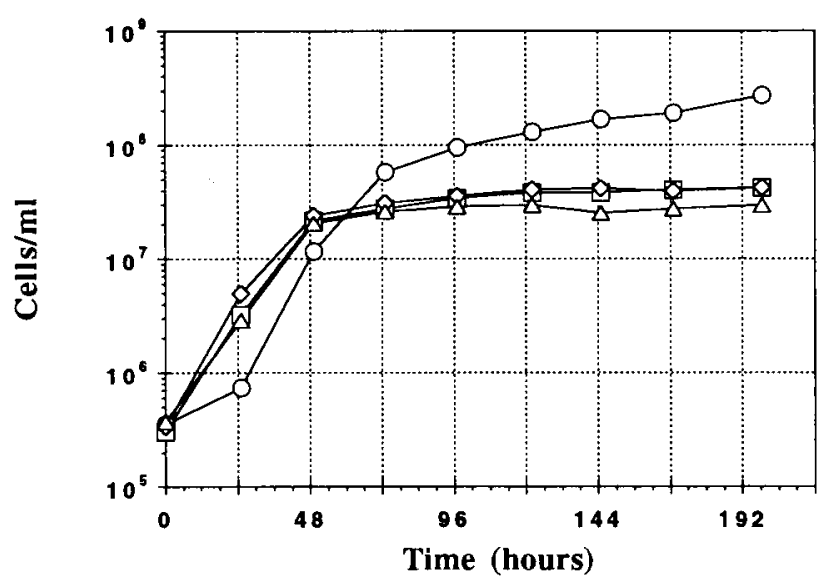

'1'
Distribution of DNA content per cell and $\mathrm{pH}$ of the culture - The distribution of DNA content per cell in all the $10 \%$ FM cultures shows unimodal distribution throughout the period of cultivation (data not shown). The $\mathrm{pH}$ of the $10 \%$ FM cultures was very steady, and only the $\mathrm{pH}$ of the $100 \%$ FM culture increased from 6.0 to 7.1 (Fig.

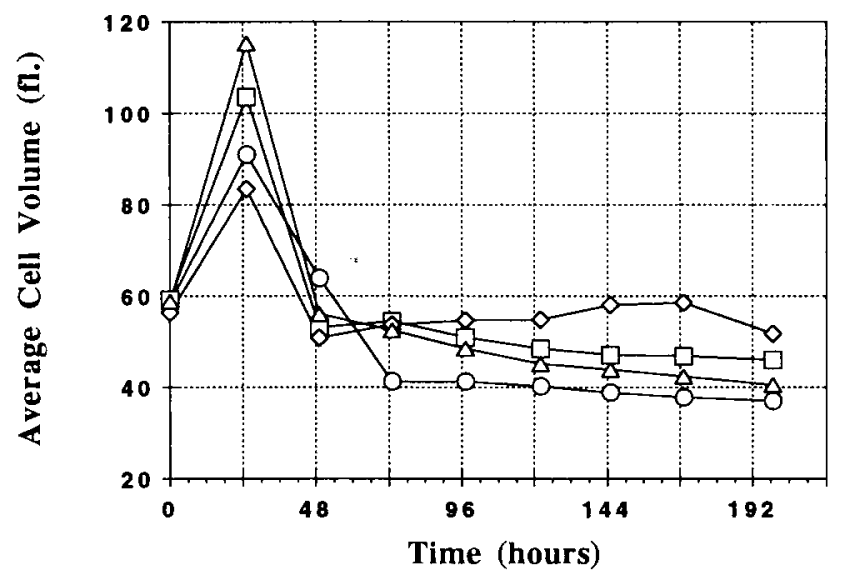

'2'

Fig. 7. Growth (1) and average cell volume (2) of $C$. vulgaris cultivated at $5 \% \mathrm{CO}_{2}$ in $100 \% \mathrm{FM}$ (circles), $10 \% \mathrm{FM}$ (squares), $90 \% \mathrm{CM}$ and $10 \%$ FM (diamonds), and $90 \% \mathrm{HCO}_{3}$-free $\mathrm{CM}$ (triangles). 

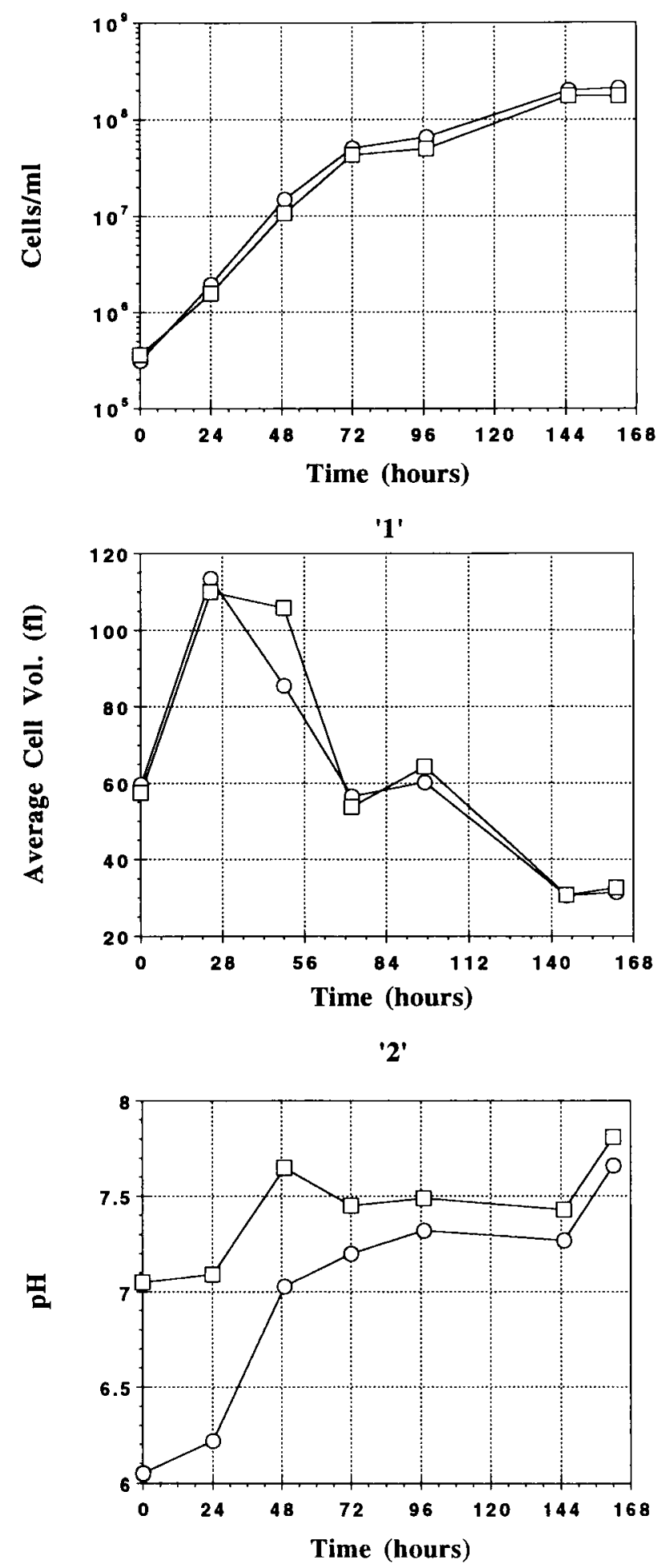

'3'

Fig. 8. Growth (1), average cell volume (2), and pH (3) of C. vulgaris cultivated at $5 \% \mathrm{CO}_{2}$ in $100 \% \mathrm{FM}$ (circles), and $90 \% \mathrm{CM}$ in $100 \% \mathrm{FM}$ (squares).
8). This $\mathrm{pH}$ increase is due to the consumption of phosphates, which results in a decrease in the buffering capacity of the medium. As expected, this increase in $\mathrm{pH}$ resulted in an increase in the dissolved inorganic content of the culture (data not shown).

\section{DISCUSSION}

The presence of autoinhibitory compounds in old cultures of Chlorella is widely cited in the literature (Krauss, 1962; Glombitza and Koch, 1989) since its initial description. This autoinhibitor has been observed to possess antibacterial activities too (Pratt et al., 1944). The results from the present study show no evidence of growth inhibitors in the culture filtrates of $C$. vulgaris. Also, attempts to identify any bacteriostatic/bactericidal activities have indicated the presence of no such compounds (Mandalam, 1994).

High concentrations $(10 \mathrm{mM})$ of bicarbonate in the $\mathrm{CM}$ have been found. The ability of $C$. vulgaris to utilize $\mathrm{HCO}_{3-}$ at low $\mathrm{CO}_{2}$ levels is well documented (Beardall, 1985; Tsuzuki, Miyachi, and Berry, 1985). The uptake of bicarbonate is initiated by the rapid conversion of extra cellular $\mathrm{HCO}_{3-}$ to $\mathrm{CO}_{2}$ by carbonic anhydrase in the periplasmic space (Miller, 1985). With every molecule of $\mathrm{HCO}_{3-}$ converted to $\mathrm{CO}_{2}$, one molecule of hydroxyl ion is released to the extracellular medium. The response of C. vulgaris under induced alkaline $\mathrm{pH}$ conditions has been studied (Malis-Arad, Friedlander, and Richmond, 1980; Malis-Arad and McGowan, 1982a, b; Guckert and Cooksey, 1990). Although the objectives of the abovementioned studies were different than that of the present study, bicarbonate was added to the culture to obtain alkaline conditions. It was found that at high $\mathrm{pH}$, certain classes of membrane lipids in Chlorella were not synthesized, resulting in the inhibition of autospore release following nuclear division (Guckert and Cooksey, 1990). Thus, bicarbonate at low carbon dioxide levels increases the culture $\mathrm{pH}$ and subsequently blocks the cells at the division stage of the cell cycle. This phenomenon was observed in the experiments reported here.

Some of the characteristics of the autoinhibitor (such as low molecular weight and solubility in organic solvents) described by Pratt and coworkers resemble the properties of bicarbonate. However, it is unlikely that the effect observed by Pratt and coworkers was due to bicarbonate since their experiments were conducted at $5 \% \mathrm{CO}_{2}$ leading to a buffered $\mathrm{pH}$.

Cells cultivated in $90 \% \mathrm{CM}$ at high carbon dioxide levels with $10 \%$ and $100 \%$ FM have clearly indicated that culture is nutrient deficient with $10 \% \mathrm{FM}$. Also, additional experiments (data not shown) have shown that the CM does not have any nutrients in it, as no growth was observed in 100\% CM cultures (Mandalam, 1994). The medium used by Pratt and coworkers had a different chemical composition (Pratt and Fong, 1940), and their results are based on the assumption that $\mathrm{CM}$ contains a fraction of all the nutrients, and the culture is not nutrient limited with 10\% FM (Pratt and Fong, 1940). This assumption is valid only if all the elements are added in the medium at the same percentage as elemental composition of cells (Oh-Hama and Miyachi, 1988). Pratt's medium when analyzed for biomass capacity was found to be deficient 
in iron at cell concentrations above $2 \times 10^{7}$ cells $/ \mathrm{ml}$. Culture filtrates for their experiments were obtained from a cell concentration of $1 \times 10^{8} \mathrm{cells} / \mathrm{ml}$ (Pratt and Fong, 1940). Also, one other investigator using Pratt's medium has failed to identify any inhibitor in old cultures of $C$. vulgaris (Scott, 1964). Taken together, the present results and those of Pratt and coworkers suggest that the described inhibitory effect may simply be due to the depletion of key components of the medium.

Several reports have suggested that the inhibitor is a photooxidation product of unsaturated fatty acid (Spoehr et al., 1949). On chemical analysis of the CM used in the experiments, it was found to contain low concentrations of methyl esters of palmitic and stearic acids. As no inhibition was observed in nutrient-supplemented $\mathrm{CM}$ cultures, it was concluded that the fatty acids were not responsible for the inhibitory effects.

Further, experiments were conducted to examine whether cells from high-density cultures were adapted to detect any inhibitory compounds in CM. Cells obtained from stationary-phase high-density cultures, when grown in nutrient-supplemented $\mathrm{CM}$ cultures at low and high initial densities, showed no such adaptation and growth inhibition (Mandalam, 1994). Thus, the conclusions stated above are not influenced by any physiological alteration in cellular properties resulting from culture conditions.

In summary, the reason for the accumulation of cells at higher DNA equivalents observed in photobioreactors may be due to the imbalance of nutrients in the medium at high cell densities and not due to the presence of autoinhibitors or physiological changes. On ultrafiltration, the deficient nutrients are replenished and the cells continue to function normally. This study concludes that old cultures of $C$. vulgaris do not secrete any auto-inhibitory compound

\section{LITERATURE CITED}

BEARDALL, J. 1985. Occurrence and importance of $\mathrm{HCO}_{3}$. utilization in microscopic algae. In W. J. Lucas and J. A. Berry [eds.], Inorganic carbon uptake by aquatic photosynthetic organisms, 83-96. American Society of Plant Physiologists, Rockville, MD.

Donnan, L., E. P. Carvill, And P. C. L. John. 1985. The cell cycle of Chlamydomonas and Chlorella. New Phytology 99: 1-40.

GlombitzA, K.-W., AND M. Koch. 1989. Secondary metabolites of pharmaceutical potential. In R. C. Cresswell, T. A. V. Rees, and H. Shah [eds.], Algal and cyanobacterial biotechnology, 161-219. Longman Scientific and Technical, Harlow, England.

GUCKERT, J., AND K. COOKSEY. 1990. Triglyceride accumulation and fatty acid profile changes in Chlorella (chlorophyta) during $\mathrm{pH}$ induced cell cycle inhibition. Journal of Phycology 26: 72-79.

Harris, D. 1970 . Growth inhibitors produced by green algae. Archiv für Mikrobiologie 76: 47-50.

produced by Pandorina morum, a colonial green flagellate. Microbios 9: 259-265.

Javanmardian, M., and B. O. Palsson. 1991a. Continuous photoautotrophic cultures of the eucaryotic alga Chlorella vulgaris can exhibit stable oscillatory dynamics. Biotechnology and Bioengineering 39: 487-497.
AND - 1991b. High-density photoautotrophic algal cultures: design, construction, and operation of a novel photobioreactor system. Biotechnology and Bioengineering 38: 1182-1189.

JORGENSEN, E. 1956. Growth inhibiting substances formed by algae. Physiologia Plantarum 9: 712-726.

Krauss, R. 1962. Inhibitors. In R. Lewin [ed.], Physiology and biochemistry of algae 673-685. Academic Press, New York, NY.

Malis-Arad, S., R. B.-A. M. Friedlander, ANd A. Richmond. 1980. Alkalinity-induced aggregation in Chlorella vulgaris. I. Changes in cell volume and cell-wall structure. Plant and Cell Physiology 21: 27-35.

AND R. MCGowAN. 1982a. Alkalinity-induced aggregation in Chlorella vulgaris. II. Changes in cell wall during the cell cycle. Plant and Cell Physiology 23: 11-17.

, AND - 1982b. A point of no return in the cell cycle of Chlorella. Plant and Cell Physiology 23: 397-401.

MANDALAM, R. 1994. Nutritional effects in high density Chlorella vulgaris cultures. Ph.D. dissertation, University of Michigan. Ann Arbor, MI.

Miller, A. 1985. Study of inorganic carbon transport: the kinetic approach. In W. J. Lucas and J. A. Berry [eds.], Inorganic carbon uptake by aquatic photosynthetic organisms, 17-30. American Society of Plant Physiologists, Rockville, MD.

Morimura, Y. 1959. Synchronous cultures of Chlorella, kinetic analysis of the life cycle of Chlorella ellipsoidea as affected by changes of temperature and light intensity. Plant and Cell Physiology 1: 4962.

Oh-Hama, T., ANd S. Mryachi. 1988. Chlorella. In M. Borowitzka and L. Borowitzka [eds.], Microalgal biotechnology, 3-26. Cambridge University Press, Cambridge.

Pratt, R. 1942a. Studies on Chlorella vulgaris. V. Some properties of the growth-inhibitor formed by Chlorella cells. American Journal of Botany 29: 142-148.

- 1942b. Studies on Chlorella vulgaris. VI. Retardation of photosynthesis by a growth-inhibiting substance from Chlorella vulgaris. American Journal of Botany 30: 32-33.

. 1944. Studies on Chlorella vulgaris. IX. Influence on growth of Chlorella of continuous removal of chlorellin from the culture solution. American Journal of Botany 31: 418-421.

— , T. C. Daniels, J. Eiler, and H. Stain. 1944. Chlorellin, an antibacterial substance from Chlorella. Science 99: 351-352.

-, AND J. FoNG. 1940. Studies on Chlorella vulgaris. II. Further evidence that Chlorella cells form a growth-inhibiting substance. American Journal of Botany 27: 431-436.

, J. F. ONeto, AND J. PRatt. 1945. Studies on Chlorella vulgaris. $X$. Influence of the age of the culture on the accumulation of chlorellin. American Journal of Botany 32: 405-408.

Scotr, J. 1964. Autoinhibitor production by Chlorella vulgaris. American Journal of Botany 51: 581-584.

Spoehr, H., J. Smith, H. Milner, AND G. Hardin. 1949. Fatty acid antibacterials from plants. Carnegie Institute of Washington, Washington, DC.

TAmiYA, H. 1964. Growth and cell division of Chlorella. In E. Zeuthen [ed.], Synchrony in cell division and growth, 247-305. Interscience Publishers, New York, NY.

-, Y. Morimora, M. Yokota, and R. Kunieda. 1961. Mode of nuclear division in synchronous culture of Chlorella: comparison of various methods of synchronization. Plant and Cell Physioiogy 2: $383-403$.

TsuzuKI, M., S. MryachI, AND J. BerRy. 1985. Intracellular accumulation of inorganic carbon and its active species taken up by Chlorella vulgaris $1 \mathrm{lh}$. In $\mathrm{W}$. Lucas and J. Berry [eds.], Inorganic carbon uptake by aquatic photosynthetic organisms, 53-66. American Society of Plant Physiologists, Rockville, MD. 